\title{
THE PREFIX “AFRICAN" AND ITS IMPLICATION FOR PHILOSOPHY IN AFRICA
}

\author{
Samuel T. SEGUN, MA \\ Department of Philosophy \\ University of Calabar, Calabar.
}

\begin{abstract}
Philosophy today is often regionalized unlike science and other disciplines. Thus we talk of Western, Eastern, American and African Philosophy. To speak or write philosophy within the ambit of the prefix "African" would elicit two major responses. First is the affirmative response which believes that indeed there exists some form of philosophy in Africa although distinct from Western philosophy in approach, procedure and methods but not in kind. The second is the denialist response which rejects vehemently the position of the former; in that they deny the existence of African philosophy independent of Western colouration. In other words, they do not believe that there exists any form of philosophy distinct from the Western idea of philosophy be it in approach or method. Within this frame certain problems arise such as the problem of interpretation or definition, the myth of unanimity and the problem of ethnophilosophy. The aim of this work thus is to understand the implications of the prefix "African" for philosophy in Africa. In this attempt, we uncover the subject of African Philosophy, its many possibilities, nature and interpretations. In understanding the implications of the prefix "African" for philosophy in Africa, the work avers that the affirmative response in modern times is an advocacy for what Chimakonam refers to as systematic African philosophy; and the denialist response to the subject is an outright rejection of the universal character of philosophy. For the laws of logic, the burden of axiology, the questions of metaphysics, the problems of sociopolitical philosophy and the concerns of epistemology all transcend geographical boundaries.
\end{abstract}

Keywords: Affirmative, Denialist, Philosophy, African, African Philosophy, Ethnophilosophy, Systematic African Philosophy, Complementarity, Unanimity.

\section{Introduction}

No scholarly write up I believe, can sufficiently exhaust the subject of philosophy in Africa. The prefix "African" when discussed alongside philosophy in Africa appropriately, presupposes the subject of African Philosophy. It designates the presence of philosophy within the continent of Africa. We must note that philosophy in Africa "means more than African Philosophy... [it refers to] the activities of doing, writing and teaching philosophy in Africa" (MAKINDE 2000, 103). As direct as this may sound it has with it attendant 
implications. The first of such implications which we shall discuss extensively in this work is the myth of unanimity. Second is the problem of equating the prefix African to a race or to the colour black or more appropriately Negro Africa. This was the challenge Leopold Senghor had to contend with in his later days when his concept of negritude was misconstrued to mean the Negro (black) race. Third is a conflict when we discuss philosophy in the context of geographical enclaves. The aim here is to question, what makes a philosophy Western, Eastern, American or African? Does philosophy change in its nature and content within cultural frames? What are the roles of geographical categorization and the content of philosophy? Fourth, there is the question of the relevance of ethnophilosophy and if it is an integral and indispensible part of African Philosophy and indeed philosophy in Africa.

As we look through different societies the content of their investigations with regards to philosophy may greatly differ in context but not in content. Much like when we refer to Philosophy in Britain, we are probing into the how philosophy is done in Britain. Likewise discussing the nature of philosophy in Africa is to question the study, teaching, writing and doing of philosophy in Africa. African philosophy as an academic study is relatively new and is often studied alongside African Studies as a mere subset. But this is not sufficient to appraise the quality of philosophy in Africa. Unfortunately but thankfully attempts are been made to ensure that academic or professional African Philosophy is studied and taught in African Universities. Prior to this attempt, philosophy students in Africa have been literally taught Western Philosophy from undergraduate to postgraduate levels. It was a hectic and tiring journey through debates, conferences and publications for African Philosophy to earn a place in the league of global philosophies. Thus, "African Philosophy as a component of academic global philosophy has become very respectable in its contributions to shaping the history and experiences of the African people and that work on African Philosophy must be persistent and sustained" (MESEMBE 2013, 122). Let us proceed to unravel the subject matter of this article accordingly; (i) Understanding the Prefix "African" (ii) Philosophy in Africa and African Philosophy (iii) Implications of the Prefix "African" for Philosophy in Africa and (iv) Understanding African Philosophy through a unified explanation.

\section{Understanding the Prefix "African"}

The prefix African refers to one with an African origin. It also refers to anything relating to Africa or Africans. It is expedient to note that in current times there has been a misconception that Africa is a country rather than a continent of many people. This has sparked tremendous reactions from Africans. Although the purpose of this may not be really known in that it could purely be an honest mistake or a calculated attempt to disposes a people of a place in global 
advancement. Whatever the reasons are, they are of little consequence to our discourse. More so, Western anthropology has made it somewhat difficult to see the African people as distinct people, a culmination of varying tribes and cultures. The etymology of the word Africa may lend us some help as we proceed:

In antiquity the Greeks are said to have called the continent Libya and the Romans to have called it Africa, perhaps from the Latin aprica ("sunny") or the Greek aphrike ("without cold"). The name Africa, however, was chiefly applied to the northern coast of the continent, which was, in effect, regarded as a southern extension of Europe. The Romans, who for a time ruled the North African coast, are also said to have called the area south of their settlements Afriga, or the Land of the Afrigs - the name of a Berber community south of Carthage. (Encyclopaedia Britannica 2011, Web., NP).

From its etymology we must note that Africa is a continent of people beyond Negro Africans. In fact the etymology of the word in no way referred to Negros. The prefix "African" therefore refers to a person from the continent of Africa.

During the scramble for Africa, it is said that "Europe's new colonial territories enclosed hundreds of diverse and independent groups, with no common history, culture, language or religion" (MEREDITH 2005, 1-2). There after the division of these territories led to the formation of many failed and failing states, historic genocides, ethnic clashes and cleansing, toggle for power and ethnic superiority etc. Thus the failure to see Africa or understand the prefix "African" from that perspective of independent groups could be counterproductive to fulfilling the aim of this work. Uduma notes strongly the words of Gene Blocker, the "word African means in the style of but they can also mean "within the geographical area of". There also appears to be a third sense which is a "person of". In the context of this third sense, on can still act or write in the "style of" or be "within the geographical area of" Africa..." $(2014,128)$. From all the above definitions, readers can glean that the prefix African refers to a person from the continent, an appurtenance of Africa, and the style of. It is within this frame of possible definition that our navigation in exploring this essay can be actualized.

\section{Philosophy in Africa and African Philosophy}

To discuss philosophy in Africa is one thing and African Philosophy another. Philosophy in Africa refers to Africa's participation in the universal enterprise of philosophy while African Philosophy presupposes a distinct way of doing philosophy. It differs from Western, Eastern or American philosophy not in kind but in approach. What do we then mean when we say we are doing philosophy? 
What is philosophy? The process of rational and critical reflection is the process of doing philosophy. And philosophy is the system that makes this reflection possible. In other words philosophy is a reflective investigation into the nature of things. As Ezeani puts it:

To philosophize is to think, and to think is to question. To philosophize is to ask questions and question the answer to the question and continue the process until one arrives at the ultimate answer- the truth... through the process of critical questioning and reflection the philosopher attempts to confront his or her existence, assumptions and also contribute to the development of thoughts. (EZEANI 2005, 11 and 7)

To deny the African this right and by this I mean the right to think is not only to question his rationality but to question his humanity and existence. Having established what qualifies as philosophy it becomes absurd when the question is there a philosophy in Africa is asked. For when we refer to philosophy in Europe or Asia, we are simply probing into how philosophy is done in Europe or Asia. Likewise discussing the nature of philosophy in Africa is to question the study, teaching, writing and practice of philosophy in Africa. The question itself appears to be self-contradictory for it appears that asking if there is a philosophy in Africa presupposes the following; first that there exists an African philosophy at least mentally- for a thing is insofar as it can be imagined, "second, (to question its) meaning, third, (its) content/nature and finally, (its) relevance" (ASIRA 2004, 197). In discussing philosophy in Africa we must necessarily discuss African Philosophy. Thankfully, "the debate or controversy on whether or not there is an African philosophy is dead and buried. At best it is a matter of mere historical interest" (UDUIGWOMEN 2009, 2). African Philosophy suggests to us a "contextualized critical thinking of or a philosophical product by an African... it is (or part of it is) an articulation by an African philosopher of his or her ideas or thoughts in a coded format meant to provide an answer to a mindboggling question or a solution to a contextualized social or political problem" (EZEANI 2005, 9). In the recent past African Philosophy has had her share of debates all tailored towards deconstructing her growing trends, ideas and influence; the problem of method, logic, criticality, etc., all featured prominently in deconstructivists arguments. But we must encourage African philosophy practitioners "...to do [philosophy] in the way they think it should be done including of course, the writing and teaching of it" (MAKINDE 2000, 125). By African Philosophy we suggest a philosophy done by Africans through reflecting on their existential ambience. Bodunrin summarizes African philosophy as "the philosophy done by African philosophers whether it be in the area of logic, ethics or history of philosophy" (SOGOLO 1993, 2). As put forward by Sodipo, "when you say African philosophy you are drawing attention to that aspect of 
philosophy which arises from a special problem and the unique experience of African people" (UDUIGWOMEN 2009, 6). An exegesis of the above definition suggests to us that African philosophy is utilizing the tools of philosophy to explain reality from the African perspective. Asukwo defines African philosophy as "a subjective world-view packaged and anchored with the mind-frame in order to ask and answer questions that can solve the immediate problem at hand within a given socio-economic and political environment" $(2009,30)$.

As is the main function of philosophy being the search for truth in its entirety (NZE 1990, 44), African philosophers must maintain this disposition if we must grow the influence of African philosophy. In fact, it is worthy to revamp the notion that African philosophy does not differ in kind or degree (in terms of hierarchy) or quality from Western or any other philosophy. They only differ in their approaches and investigation of truth. It is often argued as did Ozumba and Chimakonam that whereas Western thought is exclusive and dichotomized in nature, African thought is complementary, integrative and inclusive $(2014,80$ 85). The above corroborates our argument that Western and African philosophies differ in approach but not in kind. Chimakonam in his work "Why can't there be an African Logic?" explains further:

...among the characteristics of African logic is the uniqueness of its approach. Western logician for instance, takes the middle position between A and B and only asserts one when he has fully drawn out his proof. The African logician however, asserts one A and B before drawing out his proof to justify this position. This is principally why, by the standard of western logic any such reasoning pattern is said to be guilty of bias and prejudice and is accused of lacking in objectivity. It is by this standard that African thought pattern is said to be illogical. $(2011,143)$

What this means is that African philosophy or in the above case African logic arrives at its philosophical depth and identity through a rather different route, distinct from that applied in Western philosophy. The tenets of African philosophy "may legitimately be found in the types of literature mentioned earlier, and that its fundamental conceptual framework and content may be profitable compared with "Western philosophy" on some grounds, at least" (WRIGHT 1984, 53). In corroboration of the above, Oyeshile notes "Hence, we submit that what African philosophy is, involves the application of ... conceptual analysis, logic, criticism and synthesis to the reflections on issues that are of paramount importance to the African needs and ways of life" $(2008,62)$. To further buttress the position of this work, the above arguments insist not just on the necessity of African philosophy but on its uniqueness. 


\section{Implications of the Prefix "African" for Philosophy in Africa}

When we mention philosophy in Africa, two distinct responses are most likely to be heard. These two responses form what this work refers to as the denialist and affirmative opinions. The denialists argue that there is no philosophy in Africa. The African, they presume, is incapable of philosophizing. On the other hand the affirmatives agree that there is not only philosophy in Africa, there is also a thing known as African philosophy in the sense that we speak of Western philosophy. When philosophy is used alongside the prefix "African" what must come to mind is the universality of the subject matter of philosophy which cuts across independent groups, with no common history, culture, language or religion within the continent of Africa. The unfortunate conditioning of Western minds by anthropological literature and those of Africans by colonial indoctrination have led to a loss of individuality with regards to philosophy in Africa. We shall address certain problems this may engineer such as the myth of unanimity, ethnophilosophy and the categorization of Africa as a race or color.

\section{The Myth of Unanimity}

The Myth of Unanimity is founded on a misguided anthropological finding and belief. For there appears to be a sort of unified way of thinking, cultural response, sense of right and wrong and in this case philosophy when Western anthropologists, and many African writers express their opinions. We often hear things such as, "we Africans, the Africans" as though a uniformed way of thinking was common place in Africa. This does not exist in itself. It is rather a misconception of a people assumed to be one in thought and culture. To aptly capture this, Temples' work on the Bantus was an attempt to impose the findings of his expedition amongst the Bantus to the rest of Africa. He avers, "Anyone who claims that primitive peoples possess no system of thought, excludes them thereby from the category of men $(1959,14)$ ". Although somewhat derogatory, by primitive people he meant Negro Africans. He simply worked on the assumption that the Bantus being from the Negro race ultimately had things in common with other tribes or peoples of such race. To corroborate this further, early anthropologist and ethnographers within Africa worked with similar assumptions. The belief was that:

The central feature of the types to which African cultures belong is that there is a certain world-view to which can be related to all other central concepts, including those of religion and theology, morality and social organization. (ABRAHAM 1962, 45)

By implication, it is meant that this world-view makes African peoples similar in thoughts patterns - a thoroughly misconstrued belief. For if it were so, African 
traditional communities would have had no need for communal clashes because they would have been a homogeneous people simply living in different areas but similar in mind, thought and culture. The myth of unanimity arises when a search for a:

...common feature, theme, structure or disposition of the African traditional thoughts that will serve as the criterion for the Africanness of a philosophy...(thus) the criterion for the Africanness of a philosophy is the attempt to impose a certain metaphysics and epistemology of a certain African peoples on the whole of Africans. (UDUMA 2014, 139)

Why this myth is dangerous to the progress of African philosophy is best explained thus:

Behind this usage, then, there is a myth at work, the myth of primitive unanimity, with its suggestion that in 'primitive' societies-that is to say, non-Western societies - everybody agrees with everybody else. It follows that in such societies there can never be individual beliefs or philosophies but only collective systems of belief. (HOUNTONDJI 1983, 60)

As noted above, the damage of this claim is preposterous and an impediment to the development of African philosophy. In sincerity we must insist, as is the case that although certain characteristics flow across African communities, (which ultimately form their approach to philosophy and not content) it still doesn't make them one people. The myth of unanimity simply is a misconstrued notion that all Africans are alike in thought and beliefs. Thus when the prefix "African" with regards to a philosophy is used it often would be used to refer to a people with a common disposition to philosophy. On this myth Asouzu opines that:

...the impression is created that African philosophy is a unified body of ideas congenial to all African societies. In this case, these worldviews do not represent the ideas of concrete historical individuals; neither can they be ascribed to distinct philosophical trends in the past. $(2004,111)$

Since this is not the case, African philosophers are encouraged to disabuse their minds from writing their thoughts as if it were a thought borrowed from the community. This is thus a call for individualistic philosophy and interpretation of reality. It is a passionate call enjoining a pursuit to hear the individual's voice clearly and distinctly and different from that of the community. Critics might claim that a denial of the myth will be the denial of African philosophy. This is not the case, for to insist that there is an African philosophy different in this mode of operation but not in its content or kind from Western philosophy is not 
the same as what the myth tells us. African philosophy like the other world philosophies is confronted with matters of state, governance, beauty, art, being, knowledge and its source, morality and moral judgements, the sequence and validity of arguments etc. This will imply that it also concerns itself with branches of philosophy such as logic, epistemology, metaphysics, socio-political philosophy, ethics and aesthetics.

\section{Ethnophilosophy and Systematic African Philosophy}

When the call for evidence was made to those who argue for the existence of precolonial philosophy in Africa, the only way for justification was to produce the thoughts of sages and folklores. Literature were produce by both indigenous Africans and expatriate philosophers as means of justification. This include the works of Temples [Bantu Philosophy], Kwasi Wiredu's "The concept of Truth in Akan Language", John Mbiti and many others after them. It remains as this paper argues that these literature were products of desperation of a people deprived of an identity and a shared humanity.

Without a doubt, certain elements of philosophical importance can be found in traditional African society. Their philosophical relevance are worthy of mention. The argument against them is that they fall short of the required criticality, structure, analysis and methods of philosophy. Ethnophilosophy is a term used "derogatorily to refer to the works of those anthropologists, sociologists, ethnographers and philosophers who present the collective worldviews of the African people, their myth and folklores as philosophy" (EGBEKE 1999, 92). Hountondji believes that ethnophilosophy is a mere cultural philosophy. It is a poor attempt to systematize a worldview. Thus it falls short of the necessary reflection, critique and character of philosophy. "Ethnophilosophy is pre-philosophy mistaking itself for a metaphilosophy, a philosophy which instead of presenting its own rational justification, shelters lazily behind the authority of a tradition and projects its own theses and beliefs on to that tradition" $(1983,63)$. The challenge of ethnophilosophy is that it reemphasizes the myth of unanimity and does not appropriate philosophy to philosophers themselves but rather to a people. In the realms of ethnophilosophy, philosophy becomes a communal possession therefore losing its rigor. It is simply a debased philosophy unworthy of the name philosophy. To buttress this point further, Barry Hallen notes the challenges of ethnophilosophy which is best quoted unaltered:

(1) It presents itself as a philosophy of peoples rather than of individuals. In Africa one is therefore given the impression that there can be no equivalents to a Socrates or a Kant. Ethnophilosophy speaks only of Bantu philosophy, Dogon philosophy, Akan philosophy; as such its scope 
is collective (or 'tribal'), of the world-view variety; (2) Its sources are in the past, in what is described as authentic, traditional African culture of the pre-colonial variety, of the Africa prior to 'modernity'. These can be found in cultural by-products that were primarily oral: parables, proverbs, poetry, songs, and myths - oral literature generally. Obviously, since such sources do not present their 'philosophies' in any conventionally discursive or technical format, it is the academic scholars, rather than African peoples, who interpret or analyse them, and thus come up with what they present as the systematized 'philosophy' of an entire African culture; (3) From a methodological point of view, ethnophilosophy therefore tends to present the beliefs that constitute this 'philosophy' as things that do not change, that are somehow timeless. African traditional systems of thought are therefore portrayed as placing minimal emphasis upon rigorous argumentation and criticism in a search for truth that provides for discarding the old and creating the new. Tradition somehow becomes antithetical to innovation. Disputes between academic ethnophilosophers thus arise primarily over how to arrive at a correct interpretation of a static body of oral literature and oral traditions. (2010, 75-76)

Even with these challenges noted above, some African philosophers insist that, "...ethnophilosophy is the only philosophy that an African of black extraction can be proud of as it is rooted in African tradition and cultures" (MANGENA 2014, 96). With that said, we must ask at this point, what makes a discourse philosophy? How do we measure to what degree a discourse qualifies as philosophy? How is ethnophilosophy different from philosophy as we know it? G. Bell notes that:

Hountondji's fear was that ethnophilosophies dealt with African societies "as a voiceless face under private observation, an object to be defined and not the subject of a possible discourse," i.e., not the subject of a twoway conversation. In either form of ethnophilosophy (universalistic or pluralistic) was there a large amount of actual African philosophical literature generated, that is, philosophy written by Africans-Alexis Kagame's work being one notable exception. (2002, 23-24)

Regardless of these challenges, Bodunrin appears to warn us not to jettison ethnophilosophy because of the ready potentials it would offer in the coming days. He notes:

The African Philosopher cannot deliberately ignore the study of the traditional belief system of his people. Philosophical problems arise out of real life situations. In Africa, more than in many other parts of the modern world, traditional culture and beliefs still exercise a great 
influence on the thinking and actions of men. At a time when many people in the West believe that philosophy has become impoverished and needs redirection, a philosophical study of traditional society may be the answer. $(1984,13)$

It was with an understanding of this caution and in the light of criticisms that ethnophilosophy metamorphosed into systematic ethnophilosophy. D. A Masolo was the first to use the expression, "Systematic Ethnophilosophy" to capture Marcel Griaule's essay on the Dogon people and his interview with Ogotemmeli and all such attempts (1994, 68-83). In this work we use the expression systematic ethnophilosophy rather differently. It refers to an individualistic, critical, reflection articulated out intelligibly by an African who takes his inspiration from cultural extracts or principles. It also differs from philosophic sagacity in that it is not a search for sages and their interpretation of reality. The individual African philosopher takes this principle, clause or idea from a descriptive sense to a prescriptive level. The call for systematic ethnophilosophy is a call for a critical, reflective and rational outlook on some cultural excavations from African societies. It encourages the individuality of thoughts and the writing of these thoughts. It is a rejection of a worldview driven ethnophilosophy to an individual centred reflection of the philosophical essences of certain realities using already existing cultural ideas that best express these thoughts.

It was the works and philosophies of those Odera Oruka refers to as members of the ideological school that gave systematic ethnophilosophy a bearing. It was a proportionate and passionate attempt to gather the remains of Africa's shattered persona by piecing together valuable cultural extracts. Evidently, these were all reflected in the political thoughts of Nnamdi Azikwe, Leopold Senghor, Julius Nyerere, Kwame Nkrumah, and Obafemi Awolowo. If we insist that systematic African philosophy does not involve in any way commentaries of cultural depth like those of Temples, Kagame and all such, then critics may insist that we deny that there existed a philosophy in traditional Africa. Since this is not so, systematic ethnophilosophy refers to certain cultural excavations that serve as hypotheses for critical reflections by African scholars. These extracts could be underling principles, clauses of contemporary social relevance. In all, it suffices as non-cultural communally based commentary since it is an individualistic, thought-driven and critical pursuit to interpret reality and make intelligible input to the body of existing ideas.

Ethnophilosophy cannot be said to be systematic if it still discusses subjects like Yoruba concept of Time, Akan concept of morality, Bantu concept of being or force, Igbo concept of evil etc. Its concern must transcend cultural world views or commentaries. This is in no way rejecting the idea of and necessity of literature on such subjects. They are important subjects in the realms 
of sociology, history, ethnography and perhaps anthropology but not philosophy. On the other hand, (like what systematic ethnophilosophy advocates) a cultural principle like say, "njikoka", "ibuanyidanda" etc., which refers to the principles of Ozumba's integrativity and Asouzu's complementarity respectively, can form theoretical basis for a more critical pursuit to solving societal challenges or addressing conceptual haziness. These principles could be likened to such principles like utilitarianism, social justice, proportionate equality etc. With these cultural extracts an African philosopher can find a suitable conceptual issue to address on the impetus derived from this permutation.

\section{"African" as a Color or Race}

The failure to see Africa as a continent made up of many nations with distinct cultural backgrounds, ideas and race but as the color "black" or as "Negros" is not an uncommon phenomenon. The source of this, one may think is etymological, but it is not so. Certain stereotypes over the years have categorized all dark skinned people as Africans. The same challenge although slightly different colored the conception of negritude and black consciousness. "The assertion of black pride by members of the Negritude movement was attended by a cry against assimilation. They felt that although it was theoretically based on a belief in universal equality, it still assumed the superiority of European culture and civilization over that of Africa" (Encyclopedia Britannica 2011, N. P). Thus when the prefix African is mentioned reference is often made to the black or Negro race. Maintaining this disposition is hurtful to the advancement of African philosophy. Thus we must insist that African philosophy does not refer strictly to pre-colonial philosophy done by people of "black extraction"(MANGENA 2014, 96) but philosophy done on the Continent of Africa, a reflection of African existential realities and philosophy done by Africans. In this, we mean, a philosophy that is philosophy in its content and authorship. More instructive for us is the fact that:

... philosophy is not African on racial or linguistic lines but what makes a philosophy African is the tradition of the philosophy: African cultural experiences, history and tradition, with a grounding in an holistic ontology, which is more of co-existence with nature, rather that conquest, more of collectivism, rather that individualism, more of holism rather that atomism or monism, more of sysnthesis rather than analysis. Authentic African philosophy is that philosophy that is applied to the conceptual problems of African life. (AZENABOR 2000, 326) 
In this respect, it is of greater value to us to view the prefix African more as an a object with several tentacles than to marginalise possible definitions. Therefore, seeing the prefix "African" as a race excludes all northern African philosophers from the matrix of African philosophy.

\section{In Pursuit of a Unified Explanation for the Prefix "African" and Philosophy in Africa}

Philosophy is not the exclusive of any race and it is not a worldview. The affirmative response in modern times is an advocacy for what Chimakonam calls "systematic African philosophy" $(2014,12)$ and the denialist response to the subject is an outright rejection of the universality of philosophy. As might have been observed by attentive readers, the position of this work is that of the affirmative. But more to this, the attempt at uncovering the possible implications of the prefix "African" has been an eye opener.

Interpreting African philosophy through the lenses of the myth of unanimity, negro race or ethnophilosophy will only give us a lopsided opinion on what it means to have an African philosophy. It will be best appreciated in modern times that the pursuit of a distinct quality that makes African philosophy authentically African or what Sophie Oluwole refers to as the "Africanness" of a philosophy $(1991,214)$ may be rather inconsequential. History has shown time and time again that cultures evolve. Changes are often noted in cultures due to interactions with other cultures and so the cycle continues. Culture then becomes the sum total of mutually borrowed ideas and customs. It then will be utterly incredulous to claim that there is a Western, American, Oriental or African philosophy devoid of influence from the other. In the case of Africa, the unfortunate event of colonialism has made it impossible for us to say the continent or African philosophers are pure breed (uninfluenced) in the sense of having a special "Africanity" (KANU 2012, 53) or Africanness. There may however be certain elements that are still in their original form, they may be elements in the past; they are what Jewsiewicki, Bogumil calls the "usable past" $(1989,1)$.

A unified explanation of African philosophy will require that we first of all rid ourselves from every form of ethnocentric commitment. When we begin to lose touch of the general concern or subject matter of philosophy we begin to see African philosophy as simply the exclusive of the African. Apparently, in African universities we do Western philosophy. For us, what should qualify any study for example as Western philosophy is its approach to explanation as well as the works written by individual Western philosophers. Therefore, when I study Plato, Descartes, and Hobbes I am doing Western philosophy. The same goes for a European, if he reads the works of Asouzu on the ambivalence of human interest and not necessarily on any subject matter related to African philosophy 
per se he or she is doing African philosophy. Philosophy is universal. The laws of logic, the burden of axiology, the questions of metaphysics, the problems of socio-political philosophy and the concerns of epistemology all transcend geographical boundaries. As Ezeani notes:

Philosophy is a transcendental human phenomenon. It is not restricted to geography. European or African philosophy (localized philosophy) is a reference to the products or thoughts of some individual critical thinkers (philosophers) of that locality (e.g. Europe or Africa). Plato, for example, is regarded as a philosopher and his dualism an element of Western philosophy. But is the concept dualism (e.g. negative/positive, male/female, body/spirit, black/white) not a universal philosophical phenomenon? $(2005,18)$

The diversion from traditional African thought must not be seen as an ill omen or a gradual loss of identity. The unfortunate historical events of slavery and colonialism have ensured that the African must necessarily contend with his new personality. "There is an urgent need in Africa today for the kind of analysis that would identify and separate the backward aspects of our culture from those aspects that are worth keeping" (WIREDU 1984, 151). This is a call for what we referred to as systematic ethnophilosophy where critical reflection is made on cultural excavations such as Ibuanyidanda philosophy of Asouzu, Njikoka philosophy of Ozumba and later Chimakonam, Uwa Ontology of Iroegbu etc. An appropriate disposition must be maintained if we must be successful in our task. Asouzu $^{\mathrm{b}}$ captures this when he states:

Progress and stagnation of African philosophy depends largely on the attitude of Africans themselves who have the primary duty to patronize and promote it. In our institution of higher learning, a conducive atmosphere has to be created for the promotion and patronage of ideas, systems and methods of African philosophers in view of promoting African philosophy. That is to say, the thoughts of regional philosophers should be studied and made available to students and should be brought to compete with each other. $(2007,300)$

Thus from a unified explanation, philosophy in Africa must not be seen as regionalized philosophy but rather a contribution to the subject matter and quest of philosophy - the search for truth.

\section{Conclusion}

In conclusion we have succinctly addressed the following; (i) The prefix African (ii) Philosophy in Africa and African Philosophy (iii) Implications of the Prefix "African" for Philosophy in Africa to include the myth of unanimity, Africa as a 
color and ethnophilosophy (iv) Understanding the Prefix "African" and Philosophy in Africa from a unified explanation; insisting that we must not separate philosophy into geographical enclaves, for just as the subject matters of the physical sciences are distinct and clear and transcend geographical boundaries, philosophy possesses certain qualities that enable easy identification regardless of the shades it comes in (music, literature, folklores, stories etc.).Thus Asouzu ${ }^{c}$ notes:

In the case of philosophy, it is in view of this unity, guaranteed by a unified subject matter, that philosophy, as a discipline is sustained. In the absence of a unified subject matter, as this is a general practice in the other sciences, and which serves as a credible guide in matters of validation of our claims about the world, it becomes difficult, even today, for philosophers to speak with harmonized mind, as scientists in a way that transcends geographical and ideological boundaries. $(2007,100)$

In sum, our emphasis is to speak of African philosophy in the sense we speak of Western or other world philosophies. This identification and interpretation we believe will help the growth and progress of philosophy in Africa.

\section{Relevant Literature}

1. "Africa". [Encyclopædia Britannica Deluxe Edition], NP, 2011. Encyclopædia Britannica: Chicago. E-book.

2. ASIRA, Asira. "What is African Philosophy?", [Philosophy and Logic Today, INNOCENT Asouzu Ed.], pp196-207, 2004. University of Calabar Press: Calabar. Paperback.

3. ASOUZU, Innocent ${ }^{\mathrm{a}}$. [The Method and Principles of Complementary Reflection in and Beyond African Philosophy], 2004. University of Calabar Press: Calabar. Paperback.

4. b . [Ibuaru, The Heavy Burden of Philosophy beyond African Philosophy], 2007. Lit Verlag: Zurich. Paperback.

5 . c. [Ibuanyidanda New Complementary Ontology], 2007. Lit Verlag: Zurich. Paperback. 
6. ASUKWO, Offiong. "The Problem of Language in African Philosophy", [Footmarks to Landmarks on African philosophy UDUIGWOMEN A.F Ed.], pp30-35, 2009. Obaroh \& Ogbinaka Publishers: Lagos. Paperback.

7. AZENABOR, Godwin. "The Idea of African Philosophy in African Language" [Indian Philosophical Quarterly], pp321-328, July, 2000. Vol XXVII. No 3. E-book.

8. BODUNRIN, Peter. "The question of African Philosophy", [African Philosophy an Introduction, WRIGHT, Richard Ed.], pp1-23, 1984. University Press of America: Lanham. Paperback.

9. CHIMAKONAM, Jonathan". "Why can't there be an African Logic?”, [Integrative Humanism Journal], pp141-152, September, 2011. Vol 1. No 2. Paperback.

10._ "Dating and Periodization Question in African Philosophy", [Atuolu Omalu: Some Unanswered Questions in Contemporary African Philosophy, CHIMAKONAM, Jonathan Ed.), pp9-34, 2014. University Press of America: New York. Paperback.

11. EGBEKE, Aja. "African Philosophy: Conceptions and Problem", [Nsukka Journal of the Humanities], pp92-102, 1999. No 10. Ebook.

12. EZEANI, Emefiena. [Philosophy as Intelligent and Pragmatic Questioning], 2005. Veritas Lumen Publishers: London. Paperback.

13. HALLEN, Barry. "Ethnophilosophy Redefined?", [Thought and Practice: A Journal of the Philosophical Association of Kenya New Series], June 2010. Vol 2. No 1. Paperback.

14. HOUNTONDJI, Paulin. [African Philosophy Myth and Reality], 1983. Indiana University Press: Bloomington. Paperback. 
15. JEWSIEWICKI, Bogumil. "African Historical Studies: Academic Knowledge as 'Usable Past' and Radical Scholarship". [The African Studies Review], pp1-76, 1989. Vol 32. No 3. Web.

16. KANU, I. Anthony. "The Africanity and Philosophicality of African Philosophy", [Internet Afrrev: An International Online Multi-disciplinary Journal], pp52-54, 2012. Vol 1. No 2. Ebook.

17. MAKINDE, Akin. "Philosophy in Africa", [The Substance of African Philosophy, MOMOH, C. S. Ed.], 2000. African Philosophy Projects' Publications: Auchi. Paperback.

18. MANGENA, Fainos. "In Defence of Ethno-philosophy: A Brief Response to Kanu's Eclecticism", [Filosofia Theoretica: Journal of African Philosophy, Culture and Religion], pp96-107, JanuaryJune 2014. Vol 3. No 1. Paperback.

19. MASOLO, D.A. [African Philosophy in Search of Identity], 1994. Indiana University Press: Bloomington, Indiana. Paperback.

20. MEREDITH, Martin. [The State of Africa, A History of Fifty Years of Independence], 2005. Free Press: London. Paperback.

21. MESEMBE, Edet. "Metaphysics, Contemporary African Philosophy and Ethnocentric Commitment", [Interactions in the History of Philosophy. PHILHIST'13 Conference Proceedings, EFE Duyan, AYSE Güngör Ed.], No 778, 2013. Mimar Sinan Fine Arts University: Turkey. Paperback.

22. "Negritude." [Encyclopædia Britannica Deluxe Edition], N. P, 2011. Encyclopædia Britannica: Chicago. E-book.

23. NZE, C. "African Philosophy: Okolo's Interpretation”, [Okolo on African Philosophy and African Theology], 1990. Cecta Nigeria Ltd: Enugu. Paperback. 
24. OYESHILE, Olatunji, "On Defining African Philosophy: History, Challenges and Perspectives," [Humanity \& Social Sciences Journal], pp57-64, 2008. Vol 3. No 1. Ebook.

25. OZUMBA, Godfrey and CHIMAKONAM Jonathan. [Njikoka Amaka Further Discussions on the Philosophy of Integrative Humanism], 2014. Series Vol 2. Third Logic Option: Calabar. Paperback.

26. RICHARD, Bell. [Understanding African Philosophy A CrossCultural Approach to Classical and Contemporary Issues], 2002. Routledge: New York. Paperback.

27. SOGOLO, Godwin. [Foundations of African philosophy], 1993. Ibadan University Press: Ibadan. Paperback.

28. TEMPELS, Placide. [Bantu Philosophy], 1959. Présence Africaine: Paris. Ebook.

29. UDUIGWOMEN, Andrew. "Philosophy and the Place of African Philosophy", [Footmarks to Landmarks on African philosophy UDUIGWOMEN A.F Ed.], pp30-35, 2009. Obaroh \& Ogbinaka Publishers: Lagos. Paperback.

30. UDUMA, Uduma. "The Question of the "African" in African Philosophy: In Search of a Criterion for the Africanness of a Philosophy", [Filosofia Theoretica: Journal of African Philosophy, Culture and Religions], pp127-146, January-June 2014. Vol 3. No 1. Paperback.

31. WIREDU, Kwasia " "The Concept of Truth in the Akan Language", [Philosophy in Africa, Trends and Perspectives BODUNRIN, Peter Ed.], pp43-67, 1985. University of Ile-Ife Press: Ile-Ife. Paperback.

32. b. "How not to compare African Thought with Western Thought", [African Philosophy an Introduction, WRIGHT, 
Richard Ed.], pp149-162, 1984. University Press of America: Lanham. Paperback.

33. WRIGHT, Richard. "Investigating African Philosophy", [African Philosophy an Introduction, Richard Wright Ed.], pp41-55, 1984. University Press of America: Lanham, New York. Paperback. 